\title{
'White on the outside but red on the inside': Switzerland and Chinese intelligence networks during the Cold War
}

\author{
Published paper: Ariane Knüsel (2019): 'White on the outside but red on the inside': Switzerland \\ and Chinese intelligence networks during the Cold War, Cold War History
}

DOI: https://doi.org/10.1080/14682745.2019.1575368

\begin{abstract}
Using previously classified archival records, this article discusses how Chinese diplomatic staff operated a variety of intelligence networks from Switzerland during the Cold War. As the site of China's first diplomatic mission in central Western Europe and the location of the United Nations' European headquarters, Switzerland was uniquely suited as China's intelligence hub in Europe in the 1950s and 1960s. Chinese officials established and ran a variety of European and even global intelligence networks out of Switzerland, whose members included Taiwanese diplomats; Chinese, Taiwanese, and Chinese Indonesian scientists and students; owners and staff of Chinese restaurants; Communists and communist sympathisers; and businessmen.
\end{abstract}

\section{Introduction}

In 1964, Parade, the Sunday supplement to the Washington Post, published the article 'Red China's Spy Centre' in which it gave the following description of the Chinese Embassy in Bern:

In the gloom behind those shutters, the Red Chinese direct an underground whose agents range from the back alleys of Europe to the steamy jungles of Africa. Here sit the paymasters who through secret Swiss bank accounts bribe African politicians, foment revolution in the new African nations and finance espionage and subversion on two continents. [...] No. 10 Kalcheggweg not only houses Red China's embassy in Switzerland; it also operates schools for diplomats, propagandists, spies, saboteurs and subversives. ${ }^{1}$

Indeed, only four months after the Chinese legation had opened in Bern in December 1950, rumours were already circulating that the legation was directing China's espionage

\footnotetext{
${ }^{1}$ Jess Gorkin, 'Red China’s Spy Centre,' Parade, 22 November 1964.
} 
network in Western Europe. ${ }^{2}$ In the 1950s and 1960s, dozens - if not hundreds - of newspaper and magazines published sensational stories about Switzerland as the centre of China's espionage network in Europe with an army of spies at its disposal. For example, the Irish Independent stated: 'Red China's tentacles reach into Europe', describing the Chinese Embassy in Bern as 'a nucleus of intrigue and subversion' and the hub of China's global espionage network. ${ }^{3}$ While the Swiss government felt that such stories were ridiculous and in no way realistic, it is quite curious that these rumours circulated for decades not only in Switzerland but all over world. ${ }^{4}$ As a result, this article tries to reconstruct the reality behind the claims and takes a closer look at the role that Switzerland played in China's intelligence networks in the Cold War.

Chinese intelligence during the Cold War has remained something of an academic wasteland until now. Moreover, as William C. Hannas, James Mulvenon and Anna B. Puglisi point out: 'much of the literature on Chinese intelligence is either outdated or fatally weakened by mythology an misinformation. ${ }^{5}$ Nicolas Eftimiades and Peter L. Mattis have both written publications on the structure and methods of Chinese intelligence operations against the USA, but their portrayals differ considerably from the findings of this article, not least because this article focuses on the context of Europe in the 1950s and 1960s. ${ }^{6}$ Hannas, Mulvenon and Puglisi use Chinese official documents to discuss Chinese industrial espionage but they also tend to focus on the post Cold War-era. ${ }^{7}$ All three publications criticise the traditional 'thousand grains of sand' view of Chinese intelligence, which claims that rather than using highly trained agents, China has employed large numbers of amateur agents. ${ }^{8}$ This article, however, will show that in Europe in the 1950s and 1960s, China employed both highly trained agents sent from Beijing as well as amateurs.

While it is hardly surprising that there are no available Chinese sources on intelligence operations in Cold War Europe, almost all national archives in Europe, the USA,

\footnotetext{
${ }_{2}^{2}$ Polizei-Inspektorat Basel, 'Tätigkeit der chinesischen Kommunisten in der Schweiz,' 3 April 1951, Swiss Federal Archives (SFA) E4320B\#1981/141\#231*.

${ }^{3}$ T. Laslo, 'Red China's tentacles reach into Europe,' Irish Independent, 23 January 1967.

${ }^{4}$ Zimmermann to Loosli, 6 July 1965, SFA E2001E\#1978/84\#2315*; Meyer, 'Chinesische Spionageschule in Bern,' 30 January 1958, SFA E4320B\#1981/141\#232*; Dumont to Amstein, 9 September 1963, SFA E2001E\#1976/17\#2071*.

${ }^{5}$ William C. Hannas, James Mulvenon and Anna B. Puglisi, Chinese Industrial Espionage: Technology acquisition and military modernization (Abingdon and New York: Routledge, 2013), 186.

${ }^{6}$ Nicholas Eftimiades, Chinese Intelligence Operations (CreateSpace Independent Publishing Platform, 1994); Peter L. Mattis, 'Assessing Western Perspectives on Chinese Intelligence,' International Journal of Intelligence and CounterIntelligence 25, no. 4 (2012): 678-699.

${ }^{7}$ Hannas, Mulvenon and Puglisi, Chinese Industrial Espionage.

${ }^{8}$ Hannas, Mulvenon and Puglisi, Chinese Industrial Espionage, 189-192; Mattis, 'Chinese Intelligence,' 680681.
} 
and Canada, still classify files on Chinese intelligence in Europe. Notable exceptions are the national archives of the Netherlands and Switzerland, which have released some files to the public although most of the files by the Swiss police used in this article are still classified and have only been partially declassified for this research project. As a result of the meagre archival situation, this article relies mainly on sources from Swiss archives in order to reconstruct not only the nature of the different intelligence networks that the Chinese diplomatic staff in Switzerland built in the 1950s and 1960s but also the role that Switzerland played in these networks. The article does not focus on Swiss counterintelligence measures because this is the topic of another article. ${ }^{9}$

After the Second World War, the Swiss Foreign Minister, Max Petitpierre, used the concept of 'neutrality and solidarity' to end Switzerland's international isolation and allow Switzerland to cooperate economically and politically with the Western bloc, and establish relations with all eligible countries, regardless of their regimes' political orientation. ${ }^{10}$ As a result, when Mao Zedong proclaimed the People's Republic of China (PRC) on 1 October 1949, the Swiss government decided to recognize the new regime because it met the necessary criteria that warranted official recognition according to international law, and because recognition was thought to protect Swiss commercial interests in China and help Switzerland establish itself as a neutral mediator between East and West. ${ }^{11}$

Switzerland recognised the PRC on 17 January 1950, and the two countries officially established diplomatic relations in September 1950, with China's diplomatic staff arriving in Switzerland in December 1950. A Chinese Consulate-General opened in Geneva in March 1954, and the mission in Bern was elevated to an embassy in January 1956. ${ }^{12}$ The early opening of diplomatic missions, Switzerland's location in the centre of Europe, and the multitude of international organizations which had their (European) headquarters in

\footnotetext{
${ }^{9}$ Ariane Knüsel, 'Swiss Counterintelligence and Chinese Espionage in the Cold War,' Journal of Cold War Studies, forthcoming.

${ }^{10}$ Petitpierre, 'Speech to the National Council's Commision of Foreign Affairs,' 24 February 1948, dodis.ch/5562. See also Marina Schaufelbuehl, Marco Wyss, Sandra Bott, 'Choosing Sides in the Global Cold War. Switzerland, Neutrality and the Divided States of Vietnam and Korea,' International History Review 37, no. 5 (2015): 1014-36.

11 'Réponse à la question écrite NICOLE du 26 octobre 1949', 26 October 1949, E2001E\#1976/113\#2130*. See also: Ariane Knüsel, Framing China: Media Images and Political Debates in Britain, the USA and Switzerland, 1900-1950 (Farnham: Ashgate, 2012).

12 Petitpierre to Mao, 17 January 1950, SFA E2001E\#1967/113\#2130*; Rüfenacht, 'Rapport,' 5 December 1950, SFA E4320B\#1981/141\#231*; Mao and Zhou to Petitpierre, 18 September 1950, in 解密外交文献: 中华 人民共和国建交档案 1949-1955 Jiemi waijiao wenxian: Zhonghua renmin gongheguo jianjiao dang'an, 19491955, ed. 廉正保, 王景堂, 黄蹈鹏 Lian Zhengbao, Wang Jingtang, Huang Taopeng (北京 Beijing: 中国画报出 版社 Zhongguo huabao chubanshe, 2006), 408; 'Sitzung des Bundesrates vom 11.3.1954,' 11 March 1954, SFA E2001E\#1976/17\#2085*; Dominicé to Bernoulli, 13 January 1956, SFA E2200.174-02\#1968/3\#28*.
} 
Switzerland, were among the main reasons why China used Switzerland in the 1950s and 1960 s as the main hub for its presence in Western Europe. ${ }^{13}$ In the late 1950s and early 1960s, the Sino-Soviet Split caused China to increase its focus on relations with European countries and replace the Soviet Union as the leading socialist country. ${ }^{14}$ Thousands of surveillance reports and phone conversation analyses by the Swiss Federal Police show that the staff at the Chinese Embassy in Bern and the Consulate-General in Geneva were in contact with people from all over the world and had a variety of tasks, primarily among these were the forging and upkeep of diplomacy, business, propaganda, intelligence, and subversion networks with European contacts.

Switzerland was a popular country among foreign intelligence agencies in the Cold War due to its neutrality and diplomatic relations with Eastern and Western bloc countries, which led to a large number of diplomats in the country. Additionally, the UN's headquarters in Geneva were frequented by diplomats who were either stationed in Geneva or visited Geneva for meetings and conferences. As such, it made an excellent location for spying on other countries or meeting contacts. The British newspaper Sunday Telegraph, for example, described Switzerland as 'a happy hunting ground for foreign agents', ${ }^{15}$ and the British Ambassador in Bern concurred, stating: 'evidence suggests that even the more sensational reports appearing from time to time in the foreign press about this country may not be very wide of the mark.' ${ }^{\prime 16}$

Switzerland became the European hub of China's intelligence networks because it was the location of China's first diplomatic mission in Western Europe, and until the mid1960s none of its neighbouring countries (France, Italy, Western Germany, and Austria) had a Chinese diplomatic mission. As a result, people from these countries travelled to Switzerland whenever they wanted to meet Chinese officials. While China also had official relations with Finland, Norway, Denmark, and Sweden, Switzerland was better situated for most Europeans and had a higher concentration of diplomats. ${ }^{17}$

\footnotetext{
${ }^{13}$ Ariane Knüsel, 'Small Country - Great Importance: Switzerland and the Chinese Presence in Europe during the 1950s and 1960s,' in Europe and China in the Cold War: Exchanges Beyond the Bloc Logic and the SinoSoviet Split, ed. Marco Wyss, Janick Marina Schaufelbuehl, Valeria Zanier (Leiden: Brill, 2018).

${ }^{14}$ Jeremy Friedman, Shadow Cold War: The Sino-Soviet Competition for the Third World (Chapel Hill: The University of North Carolina Press, 2015); Lorenz M. Lüthi, The Sino-Soviet Split: Cold War in the Communist World (Princeton: Princeton University Press, 2008).

${ }^{15}$ Anthony Mann, 'Wave of Spy Activity in Switzerland,' Sunday Telegraph, 12 February 1961.

${ }^{16}$ Grey to Earl of Home, 23 February 1961, The National Archives (TNA) FO 371/161089.

17李斐仪 Li Feiyi, ‘忆出使瑞士的冯铉 Yi chushi ruishi de Feng Xuan,' in: 当代中国使节外交生涯 Dangdai zhongguo shijie waijiao shengya, vol. 1 (Beijing: 世界知识出版社 Shijie zhishi chubanshe, 1995), 173-174; Knüsel, 'Small Country.'
} 
Swiss counterintelligence was headed by the Office of the Attorney-General (OAG) and its police force, the Federal Police. The government's insistence that the OAG's counterintelligence should focus on the investigation and prosecution of people and organizations that threatened Swiss internal and external security created some grey areas in which foreign intelligence agents could operate. ${ }^{18}$ The Federal Police were well aware that Eastern and Western diplomatic missions and international organizations included intelligence officers among their staff. However, Swiss anticommunism caused the Federal Police to identify Eastern bloc spies as the main threat to Swiss security, and to collaborate with several Western agencies and police forces. ${ }^{19}$ Since China belonged to the Eastern bloc, all Chinese diplomatic staff were suspected of being potential intelligence officers, and the Chinese Embassy in Bern as well as the Consulate-General in Geneva were observed for evidence of intelligence activity. ${ }^{20}$

\section{Chinese Diplomats as Intelligence Agents}

The Chinese missions in Switzerland were infamous for their unusually high number of staff. In January 1958, for example, a total of 100 Chinese diplomatic staff (including wives) lived in Bern and Geneva. ${ }^{21}$ This number did not change a great deal over the next few years, making China the country with the second or third highest number of diplomatic staff in Switzerland after the USA and the Soviet Union. Although the Federal Police suspected that some of the Chinese officials were involved in espionage, they did not judge it to be a serious problem. ${ }^{22}$ However, a Federal Police report from 1962 stated: 'It is very difficult to obtain information about the activity of the Chinese officials in Switzerland. Contrary to other diplomatic missions, even those from Eastern countries, the Chinese only provide parsimonious information about each official in our country.' Thus, the Federal Police were only informed of a quarter of the 85 Chinese officially employed at the Embassy in Bern in

\footnotetext{
18 'Botschaft des Bundesrates an die Bundesversammlung zum Entwurf eines Bundesbeschlusses betreffend den Schutz der Sicherheit der Eidgenossenschaft und die Erweiterung der Bundesanwaltschaft,' 29 April 1935, Bundesblatt 1, no.18 (1935): 742-748.

19 ‘Aktion W.O.N.,' January 1966, SFA E4320C\#1994/78\#770*; Zwischenbericht zur Sicherheitspolitik vom 3. Dezember 1979', Bundesblatt 1 no. 5 (1980): 363; 'Vortrag von Herrn Oberstleutnant Kern über Sicherheitsprobleme anlässlich der Botschaftertagung 1964', 4 September 4 1964, dodis.ch/30820. See also: Luc Van Dongen, 'De la place de la Suisse dans la "guerre froide secrete” des Etats-Unis, 1943-1975,' Traverse 2 (2009), 55-72; Riccardo Tarli, Operationsgebiet Schweiz: Die dunklen Geschäfte der Stasi (Zürich: Orell Füssli Verlag, 2015).

${ }^{20}$ Knüsel, 'Swiss Counterintelligence.'

${ }^{21}$ Caviezel, 'Personalbestand der Chinesischen Botschaft in Bern,' 6 January 1958, SFA E4320B\#1981/141\#232*.

${ }^{22}$ Hunziker, 'Personal der chinesischen Botschaft in Bern,' 14 February 1959, SFA E2001E\#1976/17\#2078*.
} 
1962. This was even more problematic according to the report because 'Switzerland has to be considered as a centre or a hub for Chinese activity in Western Europe. ${ }^{23}$

A Federal Police report from 1964 claimed that Chinese intelligence officials in Bern and Geneva were in charge of specific contact networks or areas of expertise, such as European communists and Communist Parties; French businessmen; Chinese in Europe; Swiss companies and factories; Italy, Spain and Latin America; propaganda in Western Europe; topographic maps and plans; and military and economic publications. ${ }^{24}$ Depending on the intelligence network that they were in charge of, some agents had to travel more than others to meet their sources and gather intelligence. In most cases, however, the agents seem to have met their contacts at the Embassy, the Trade Office or the Consulate-General.

Although many newspapers and magazines claimed that the Chinese missions in Switzerland had hundreds of agents at their behest, this number was clearly too high. In 1966, 97 diplomats and officials were registered as working for the Chinese Embassy, the Trade Office, and the Consulate-General. Among these, the Federal Police suspected 30 intelligence officers and an additional 30 officials who carried out intelligence tasks. The Cultural Revolution changed this drastically though, as most staff were called back to China for what were euphemistically described as re-education purposes. Thus, by August 1967, there were only 37 Chinese diplomats and officials left in Switzerland. ${ }^{25}$ Moreover, the opening of the Chinese Embassy in Paris also caused intelligence officers to be moved from Bern and Geneva to Paris. ${ }^{26}$

There were also several entirely legal reasons for China's large number of staff: Until the mid-1960s, China's commercial, scientific, and diplomatic contacts with Switzerland's neighbouring countries were handled by Bern. Contrary to other diplomatic missions, the Chinese also brought almost their entire staff with them - including chefs and drivers - and Chinese students were sent to Geneva to study French. Additionally, the Embassy in Bern managed most Western delegations that were invited to China, and Chinese delegations

\footnotetext{
${ }^{23}$ Babey, 'Note à l'intention de M. le Procureur général,' 20 July 1962, SFA E4320C\#1994/78\#800*. All quotes were translated by the author.

${ }^{24}$ Bürgy, 'Zusammenfassender Bericht über die mit der chinesischen Botschaft in Verbindung stehenden Personen und Firmen,' 28 January 1964, SFA E4320C\#1994/78\#755*.

25 'Bericht der Bundespolizei betreffend ihre Feststellungen über die Tätigkeit der diplomatischen und konsularischen Vertretungen der Volksrepublik China in der Schweiz,' 1 September 1967, SFA E2001E\#1978/84\#2315*.

${ }^{26}$ Bürgy, 'Zusammenfassender Bericht über die mit der chinesischen Botschaft in Verbindung stehenden Personen und Firmen,' 28 January 1964, SFA E4320C\#1994/78\#755*. For France's recognition of China see Garret Martin, 'Playing the China Card? Revisiting France's Recognition of Communist China, 1963-1964,' Journal of Cold War Studies 10, no 1(2008): 52-80; Lorenz M. Lüthi, 'Rearranging International Relations? How Mao's China and de Gaulle's France Recognized Each Other in 1963-1964,' Journal of Cold War Studies 16, no. 1 (2014): 111-145.
} 
visiting (Western) Europe. Finally, the Sino-Soviet Split led to China increasing its presence in Latin America and Africa by opening embassies, Xinhua offices, and trade offices there. Many Chinese officials travelled to these places via Switzerland. Officially, they stopped in Switzerland to get visas for their destination. However, since they often stayed several days to a week, it is likely that at least some of these officials came to Bern to receive instructions or to report, particularly since a good number of them were active as intelligence agents. ${ }^{27}$

Another type of intelligence agent was the Xinhua journalist. Xinhua was in charge of propaganda abroad. ${ }^{28}$ After Mao declared in 1955 that the news agency should increase its international presence and send more journalists abroad to make China's voice heard in the world, the number of Xinhua offices abroad increased from 10 in 1956 to 51 by $1965 .{ }^{29} \mathrm{In}$ July 1957, a Xinhua office was opened in Paris under the leadership of Yang Xiaonong, followed by an office in Geneva under the leadership of Chen Xiuyu in February 1958. ${ }^{30}$ Officially designated as journalists, the Xinhua employees' main job was to collect information about their host country but they also acted as intermediaries between missions in different countries. In 1962, Yang Xiaonong became the official Xinhua correspondent in Geneva, causing him to often travel between Paris, Geneva, and Bern, thereby acting as middleman between the missions in Switzerland and the Embassy in Paris. ${ }^{31}$ This was, of course, an ideal position for an intelligence agent, and a Federal Police report from 1964 described Yang as 'the driving force of the Chinese intelligence service in Western Europe, whose reach runs from New York to Paris to Bern. His central location allows him to

\footnotetext{
${ }^{27}$ Bürgy, 'Zusammenfassender Bericht über die mit der chinesischen Botschaft in Verbindung stehenden Personen und Firmen,' 28 January 1964, SFA E4320C\#1994/78\#755*; Zimmermann to Loosli, 6 July 1965, SFA E2001E\#1978/84\#2315*; Caviezel, 'TAB Chinesische Botschaft in Bern,' 5 June 1958, SFA E4320B\#1981/141\#232*; Keller, 'Personalbestand der chinesischen Botschaft,' 16 February 1965, E2001E\#1978/84\#2317*; Kohli to Eidgenössische Fremdenpolizei, 2 March 1961, SFA 2001E\#1976/17\#2085. See also: Friedman, Shadow Cold War, 25-100; Marisela Connelly and Romero Cornejo Bustamante, ChinaAmérica Latina: Génesis y desarrollo de sus relaciones (México: El Colegio de México, 1992), 58-83; Leonardo Ruilova, China Popular en America Latina (Quito: Instituto Latinoamericano de Investigaciones Sociales, 1978), 123-151.

28 陈佩明 Chen Peiming, “一代新华人奋力 拼搏创新业 Yidai Xinhua ren fenli pinbo chuangxin ye,' in 走 向世界一新华社国际报道70年 Zouxiang shijie: Xinhuashe guoji baodao 70 nian, ed. 马生荣编 Ma

Shengrong (Beijing: 新华出版社 Xinhua chubanshe，2001), 95.

${ }^{29}$ 王树柏 Wang Shubo, “国际新闻报道70年回顾 Guoji xinwen baodao 70 nian huigu, in 走向世界一新华社 国际报道70年 Zouxiang shijie: Xinhuashe guoji baodao 70 nian, ed. 马生荣编 Ma Shengrong (Beijing: 新华 出版社 Xinhua chubanshe, 2001), 57-59.

30 新华社国外及港，澳，分社（总分社）简社一览表 Xinhuashe guowai ji Gang, Ao, fenshe (zongfen she) jian she yilanbiao', in 走向世界—新华社国际报道70年 Zouxiang shijie: Xinhuashe guoji baodao 70 nian, ed. 马生荣编 Ma Shengrong (Beijing: 新华出版社Xinhua chubanshe, 2001), 576-577.

${ }^{31}$ Chinese Embassy to EPD, 29 August 1962, SFA E2001E\#1976/17\#200*; Bachofner to Meyer, 15 March 1960, SFA E4320C\#1994/78\#545*; Bürgy, 'Zusammenfassender Bericht über die mit der chinesischen Botschaft in Verbindung stehenden Personen und Firmen,' 28 January 1964, SFA E4320C\#1994/78\#755*.
} 
coordinate messages from the entire Western world in Paris and then forward them via Bern and Geneva to Beijing.' 32

\section{Taiwanese Informants}

Traditionally, Chinese intelligence has been described as relying solely on ethnic Chinese for their intelligence operations, but Mattis, and to a lesser extent Hannas, Mulvenon and Puglisi have disputed this. ${ }^{33}$ While it certainly was not the case that China only used ethnic Chinese as informants and agents in Europe, in the 1950s and 1960s they were in the majority. Among China's intelligence networks that were run from Switzerland, for example, was one that consisted almost solely of Taiwanese spies and informants. ${ }^{34}$ Switzerland had no official relations with Taiwan due to China's insistence on the One-China policy, but Taiwanese working for the UN or other international organizations often travelled to Geneva or were stationed there. These Taiwanese were of particular interest to Chinese intelligence agents, and dozens of them became informants, some even agents. Interestingly, many Taiwanese who were identified as informants or agents worked for the UN in New York. ${ }^{35}$ They used work-related trips like conferences and other meetings to the UN in Geneva to visit the Chinese Consulate or meet with Chinese diplomatic staff during their stay in Geneva and hand over classified information. Usually, they called the Consulate and arranged for a meeting, which would take place at the Consulate or in another location. In one case, a Taiwanese who worked for the $\mathrm{UN}$ as a translator brought so many documents that the Chinese diplomat who met him had to take a taxi back to the Consulate because he could not carry them all. ${ }^{36}$ Those who could not travel personally to Geneva from New York sent their information to Shi Zhengxin, a Taiwanese working for the WHO in Geneva, who then handed it over to an official from the Chinese consulate. Shi received mail from Taiwanese

\footnotetext{
${ }^{32}$ Bürgy, 'Zusammenfassender Bericht über die mit der chinesischen Botschaft in Verbindung stehenden Personen und Firmen,' 28 January 1964, SFA E4320C\#1994/78\#755*.

33 Paul D. Moore, 'How China Plays the Ethnic Card: Beijing's Strategy of Targeting Chinese Americans Is Hard to Counter With U.S. Security Defense,' The Los Angeles Times, 24 June 1999, http://articles.latimes.com/1999/jun/24/local/me-49832; Nicolas Groffman, 'Indian and Chinese espionage,' Defense \& Security Analysis 32, no. 2, (2016), 148; Mattis, 'Chinese Intelligence', 680-682; Hannas, Mulvenon and Puglisi, Chinese Industrial Espionage, 195-199.

34 'Bericht der Bundespolizei betreffend ihre Feststellungen über die Tätigkeit der diplomatischen und konsularischen Vertretungen der Volksrepublik China in der Schweiz,' 1 September 1967, SFA E2001E\#1978/84\#2315*.

${ }^{35}$ Li Kenong to Petitpierre, 10 February 1950, SFA E2001E\#1967/113\#2130*; Micheli to Fürst, 22 June 1966, SFA E2001E\#1978/84\#2318*; 裴坚章 Pei Jianzhang (ed.), 中华人民共和国外交, Zhonghua renmin gongheguo waijiao shi, vol. 1 (Beijing: 世界知识出版社 Shijie zhishi chubanshe, 1994).

${ }^{36}$ Ritschard, 'Note,' 10 July 1964, SFA E4320C\#1994/78\#547*.
} 
UN employees in France, Belgium, Germany, Italy, Austria, and even South Korea. Most of the Taiwanese informants had been born in China. Some had parents in the PRC, others were communist sympathisers, or wanted to move to China. ${ }^{37}$

Among Shi's contacts was Guo You-shou. Guo was Cultural Attaché at the Taiwanese Embassy in Brussels and Council at Taiwan's permanent delegation at UNESCO in Paris. He had been an agent for the Chinese Embassy in Bern for 12 years when he was arrested in Geneva in February 1966. Guo was recruited in 1954, when he was invited to dine with the Chinese Minister Feng Xuan in Bern, where Feng proposed collaboration for a unified China. Guo subsequently travelled to Bern several times a year, providing information on the Taiwanese government and on over 100 Taiwanese diplomats, tourists, and UN officials, discussing which Taiwanese were loyal to their government, and which might be willing to work for China. Guo went on at least 35 intelligence missions in Switzerland alone but he was also active in Brussels. He received approximately USD 40,000 from Chinese officials in Switzerland, and the Chinese government also financially assisted his ex-wife and children in China. Between the meetings, Guo wrote over 100 letters to his contacts at the Embassy using the pseudonym Kang or to Shi who then passed them on to the Consulate. ${ }^{38}$

While Guo and Shi were expelled for illegal political intelligence activity in Switzerland, and Shi was transferred by the WHO, Guo's main Chinese contact, Wang Erhkang, Second Secretary at the Embassy in Bern, was declared persona non grata, and entry bans were issued against five other contacts who were not stationed in Switzerland anymore. However, no measures were taken against Consul-General Chao Hsing-chih, and the official press release did not mention any names or specific details. The Federal Council also issued a gagging order to the press in order to avoid further aggravating Sino-Swiss relations. ${ }^{39}$ According to Frederick L. Wettering, the expulsion of spies with a diplomatic cover is fairly rare because governments try to avoid retaliation or damaging commercial or political

\footnotetext{
${ }^{37}$ Micheli to Fürst, 22 June 1966, SFA E2001E\#1978/84\#2318*; 'Bericht der Bundespolizei betreffend ihre Feststellungen über die Tätigkeit der diplomatischen und konsularischen Vertretungen der Volksrepublik China in der Schweiz,' 1 September 1967, SFA E2001E\#1978/84\#2315*; Babey, 'Note à l'intention de M. le Procureur général,' 20 July 1962, SFA E4320C\#1994/78\#800*.

${ }^{38}$ von Moos, 'Enquête dirigée contre le ressortissant de la China nationaliste KUO Yu-shou', 11 March 1966, SFA E2001E\#1978/84\#2316*; Eidgenössisches Politisches Department (EPD), 'Rapport joint concernant la proposition du Département de justice et police du 11 mars 1966,' SFA E2001E\#1978/84\#2316*

${ }^{39}$ Micheli, 'Expulsion du Dr Tsung-sing SZE,' 31 March 1966, SFA E2001E\#1978/84\#2318*; EPD to Embassy in Beijing, 'Telegramm Nr. 23,' 21 March 1966, SFA E2001E\#1978/84\#2316*; Bundeskanzlei, 'Mitteilung,' 24 March 1966, SFA E2001E\#1978/84\#2316*; 'Sitzung des Schweizerischen Bundesrates, Auszug aus dem Protokoll,' 21 March 1996, SFAE2001E\#1978/84\#2318*; Janner to Keller, 25 March 1966, SFA E2001E\#1978/84\#2316*.
} 
relations.$^{40}$ China protested the Swiss measures, claiming that the charges had been invented by the Swiss authorities in collaboration with Chiang Jieshi. ${ }^{41}$

Guo's case was typical to the extent that Chinese officials in Switzerland ran a network of Taiwanese informants and spies, and that the Swiss government tried to downplay the case towards the media to avoid further aggravating Sino-Swiss relations and protect the Swiss diplomats in Beijing. Although it was a big deal at the time, the Guo affair does not seem to have affected Chinese intelligence networks run from Switzerland a great deal. Wang, who was forced to leave Switzerland, had been in charge of a network of Taiwanese contacts in several Western countries whom he recruited when they turned to the Embassy in Bern or the Consulate in Geneva to obtain visas. He was replaced by Chen Wen-Kuei, who not only continued to run Wang's network but also recruited more informants, while ViceConsul Pi Hsien-sheng was thought to be in charge of the Taiwanese UN officials. ${ }^{42}$

\section{Expat Networks}

Almost immediately after their arrival in Switzerland in December 1950, the Chinese diplomats reached out to students in Switzerland and other European countries. ${ }^{43}$ Hannas, Mulvenon and Puglisi have shown that since 1949, China has been sending students abroad in order to receive scientific training. While Hannas, Mulvenon and Puglisi focus on the period after 1978 in the USA, there are several similarities to the situation in the 1950s and 1960s in Europe, for example the fact that most Chinese students abroad studied engineering and sciences, and the fact that the Chinese government actively encouraged them to return to China. ${ }^{44}$ However, the Chinese officials in Switzerland not only targeted Chinese students in Europe but also ethnic Chinese students like Taiwanese and Chinese Indonesians. The main reason for this was probably that there were simply not enough Chinese students in Europe.

In the 1950s and 1960s, the Chinese Embassy in Bern often held events for Chinese and Taiwanese students, including dinners, film screenings, and receptions. While not all attendees were likely won over, the free food and drinks as well as the invitation and the flattery might have enticed some of them to establish relations with individual diplomats.

\footnotetext{
${ }^{40}$ Frederick L. Wettering, 'Counterintelligence: The Broken Triad,' International Journal of Intelligence and CounterIntelligence 13, no. 3 (2000), 281.

${ }^{41}$ Janner, 'Notice,' E4320C\#1994/78\#796*.

42 'Bericht der Bundesanwaltschaft über Chen Wen-Kuei,' 12 February 1968, SFA E2001E\#1976/17\#2071*.

43 'Note Confidentielle concerne l'activité de l'Ambassade de Chine à Berne,' 4 July 1956, SFA E4320B\#1981/141\#231*; Ackerhans, 'Rapport', 4 January 1951, SFA E4320B\#1981/141\#231*.

${ }^{44}$ Hannas, Mulvenon and Puglisi, Chinese Industrial Espionage, 136-157.
} 
Once contact had been established, the students usually travelled to Bern or Geneva a couple of times a year, where they met with a Chinese diplomat. In return for passing on intelligence about compatriots and student organizations, they received money to cover tuition and/or travelling expenses. Their parents sometimes also received the right to return to China or received preferential treatment if they already lived in China. Taiwanese students, in particular, seemed to have chosen to act as informants for China in order to enable themselves or their parents to return to the PRC. Meanwhile, other students seemed to have relied on Chinese money to finance their stay in Europe. ${ }^{45}$

In the 1950s, the legation in Bern established contact with dozens of Chinese, Taiwanese, and Chinese Indonesian students in Switzerland, France, Germany, the Netherlands, and other European countries. While the actual process of establishing contact with the students is unclear in most cases, students seem to have been targeted because they studied physics, engineering or chemistry. ${ }^{46}$ The Embassy's interest in science students was connected to China's thirst for scientific knowledge and technological know-how during the Cold War period. Not only did China aim to modernise at breakneck speed, the NATO powers' embargo also made it impossible for China to import technology from the West that could be used as war material or for China's nuclear program. As John Wilson Lewis and Xue Litai have shown, China sent thousands of students abroad to study nuclear engineering and nuclear science in the 1950s, and it also increased its efforts to convince scientists and engineers abroad to return. ${ }^{47}$ While Lewis and Xue date these efforts from the mid-1950s, they actually began much earlier: When the Chinese mission in Bern held a reception for Chinese expats in January 1951, the diplomats were particularly interested in scientists and students, and Minister Feng Xuan even stated that students should return to China after graduating and assist in the country's development. ${ }^{48}$

Chinese officials in Switzerland usually told the recruited students to finish their studies in Europe, then work for companies where they could acquire know-how that would benefit China, and eventually return to China. As a result, from the early 1950s on, Chinese, Taiwanese and Chinese Indonesian engineers and physicists as well as engineering and

\footnotetext{
${ }^{45}$ Babey, 'Note à l'intention de M. le Procureur général,' 20 July 1962, SFA E4320C\#1994/78\#800*; Polizeidienst, 'Abhörungsprotokoll,' 14 March 1963, SFA E4320C\#1994/78\#608*; Note Confidentielle concerne l'activité de l'Ambassade de Chine à Berne,' 4 July 1956, SFA E4320B\#1981/141\#231*. ${ }^{46}$ See for example Verbindung IV, 'Nachrichtendienstaktivitäten der chinesischen Botschaft in Bern,' SFA E4320C\#1994/78\#547*.

${ }^{47}$ John Wilson Lewis and Xue Litai, China Builds the Bomb (Stanford, Standford University Press 1988), 36-39 and 105-106. For China's reactions to the embargo see Shu Guang Zhang, Beijing's Economic Statecraft during the Cold War, 1949-1991 (Washington, D.C.: Woodrow Wilson Center Press, 2014), 21-95.

${ }^{48}$ Ackerhans, 'Rapport', 4 January 1951, SFA E4320B\#1981/141\#231*.
} 
physics students could be found among the contacts who regularly visited the Embassy in Bern and the Consulate in Geneva. ${ }^{49}$ The only Chinese account that mentions these contacts is by Li Feiyi, who claims that all the Embassy did was explain to these people how the 'new China' really was and thereby convinced many scientists to return to China. ${ }^{50}$

Not all students were supposed to return to China. China's relations with Indonesia were rather turbulent during the 1960s, and the Chinese Embassy in Bern tried to gain access to Chinese Indonesian student communities in Europe. Some recruited students received financial assistance in return for providing information on fellow Chinese Indonesians and the government. A Chinese Indonesian student who was groomed as a future spy was told to return to Indonesia after finishing his studies in Switzerland. His handler at the Embassy also told him that he should be politically inconspicuous in Indonesia and Switzerland and stay 'white on the outside but red on the inside'. ${ }^{1}$

Another group of expats in Switzerland were Tibetans. After the Tibetan uprising in 1959, the Swiss government allowed 1000 Tibetan refugees to settle in Switzerland, which became the largest Tibetan community in Europe. In 1968, the Tibetan Institute was opened in Rikon. In the 1960s, Chinese officials repeatedly described the several hundred Tibetans in Switzerland as 'rebels' and 'bandits', and accused the Swiss government of supporting their anti-Chinese agitation in Switzerland. ${ }^{52}$ However, according to the available archival files, Tibetan refugees in Switzerland did not seem to have been a primary target of Chinese agents in Switzerland. In 1968, the Chinese Embassy's car was spotted stopping next to the Tibetan Institute and then driving away, and a Chinese scientist working in France who was suspected of being an agent for the Chinese Embassy in Paris travelled near to Rikon several times. Other than that, however, the Federal Police did not seem to have come across information about Chinese intelligence agents interacting with Tibetans in Switzerland or targeting them specifically. ${ }^{53}$ Of course, this could be because the Chinese were too clever for the Swiss Police or because the files are still buried somewhere in the archives. It certainly seems

\footnotetext{
${ }^{49}$ Polizeidienst, 'Abhörungsprotokoll,' 14 March 1963, SFA E4320C\#1994/78\#608*; Bundesanwaltschaft, 'Bericht der Bundesanwaltschaft über Chen Wen-Kuei,' 12 February 1968, SFA E2001E\#1976/17\#2071*; Bailly, 'Rapport,' 31 July 1962, SFA E4320C\#1994/78\#792*.

50 李 $\mathrm{Li}$, ‘忆出使瑞士的冯铉 Yi chushi ruishi de Feng Xuan,' 174.

${ }^{51}$ Leuenberger and Stahel, 'Politischer Nachrichtendienst, Art. 272 StGB,' 5 January 1968, SFA E2001E\#1976/17\#2071*.

52 ‘Aufnahme von tibetischen Flüchtlingen,’ 29 March 1963, Dodis.ch/18992; 李清泉, “瑞士七年,”61. See also: Ariane Knüsel, “'Armé de la pensée Mao Tsé-toung, on peut résoudre tous les problèmes”: l'influence de la Révolution culturelle sur les relations de la Suisse avec la République populaire de China,' Relations Internationales 3:163 (2015): 36-38.

${ }^{53}$ Staub, 'Tibet-Institut in Rikon/ZH im Tösstal', 7 November 1968, SFA E4320C\#1994/78\#770*; Staub, report, 6 December 1968, SFA E4320C\#1994/78\#604*.
} 
implausible that Chinese intelligence did not also target Tibetans in Switzerland.

\section{Chinese Restaurants}

Chinese restaurants were also part of China's intelligence networks in Europe, as they were a typical line of work for Chinese emigrants. In Switzerland, the Federal Police suspected all Chinese restaurants of having ties to the Chinese Embassy. As a result, they were observed closely by the local police forces. In some cases, phone lines were tapped and mail was opened, but usually the observation was more casual. Switzerland was not the only country where Chinese restaurants were put under surveillance: In Belgium, the Netherlands, and France restaurants were also watched. ${ }^{54}$ The Netherlands even went as far as refusing work permits for Chinese planning to work in Chinese restaurants in 1965, a measure aimed at stopping Chinese subversion and intelligence activities. ${ }^{55}$ The Swiss immigration authorities were also rather reluctant to grant entry visas and work permits to Taiwanese and Chinese who wanted to work in Chinese restaurants. ${ }^{56}$ In one case at least, their initial reluctance turned out to be justified. After a Taiwanese was allowed to enter Switzerland and work as a chef in a Chinese restaurant in Zurich, he had intensive contact with the Chinese Embassy, causing a Federal Police officer to write: 'The authorities of Canton Zurich have obviously been duped by $[\mathrm{X}]$. His future stay [in Switzerland] should be denied based on immigration police reasons.' 57

In 1966, the German magazine Der Spiegel declared with regards to Chinese restaurants in Germany: 'In Chinese restaurants the phones are often connected to a tape recorder that intelligence-trained chop-suey-chefs listen to after closing time. ${ }^{58}$ Rumours about the nefarious or illegal side of Chinese restaurants seems to have been common all over Europe, but since the records on this topic are still classified in most countries, it is impossible to get a clear picture of the actual role played by Chinese restaurants in China's intelligence networks during the Cold War. In the early 1960s, some French, German, and Belgian restaurants with ties to the Chinese missions in Switzerland were suspected of being used for Chinese intelligence activities. According to the Belgian authorities, people connected to Chinese restaurants in Belgium had contacts to Chinese restaurants in France

\footnotetext{
${ }^{54}$ Kommissariat IV, 'Notiz,' 5 January 1967, SFA E4320C\#1994/78\#766*.

55 AFP, 'Dutch move against Chinese restaurants.' China Mail, 1 December 1965.

${ }^{56}$ Hefelin to Eidgenössische Fremdenpolizei, 3 December 1965, SFA E4320C\#1994/78\#695*.

${ }^{57}$ Leuenberger, Report, 26 July 1968, SFA E4320C\#1994/78\#695*.

58 'Spionage,' Der Spiegel, 22 August 1966.
} 
and Switzerland. Some Chinese restaurants in Belgium even received money from the Chinese Embassy in Bern. In one instance, the money trail was traced from Switzerland to France and then on to Belgium. ${ }^{59}$

The situation in Switzerland seems to have been a lot more low key, if not boring. A Federal Police report from March 1960 stated: 'The Red Chinese have without doubt certain relations with the staff of these restaurants, but we do not know the actual reason for this. In any case, these restaurants are a good opportunity to distribute (Red Chinese) information publications and to observe members of the Chinese colony, as well as the inconspicuous handover of agents' reports. ${ }^{60}$ While this sounds quite juicy, the reality seems to have been much less so. There was a marked increase in applications for work visas from Chinese for Chinese restaurants in Switzerland in the 1960s, but among the Chinese restaurants in Switzerland, only a handful were deemed to have been active participants in Chinese intelligence networks, namely a restaurant in Geneva and one in Zurich. Interestingly, employees from both restaurants also had contact with people working in Chinese restaurants in France that had ties to Bern, which again hints at an international intelligence network using Chinese restaurants. ${ }^{61}$ Nevertheless, the lack of evidence so far seems either to indicate that Chinese restaurants in Switzerland were not actually staffed with intelligence agents, or were not used as primary locations for China's intelligence activities. Instead, it could be argued that Chinese restaurants were where the majority of Chinese and Taiwanese immigrants worked, and so the chance of finding an informant or even a spy at a Chinese restaurant was obviously high. Moreover, there were also cases in which people asked the Embassy staff to please not phone a Chinese restaurant because they did not want the staff to know that they were in contact with the Embassy. ${ }^{62}$

\section{Communist Networks}

China was very active in cultivating support in Europe. So-called 'friendship associations' were given special treatment with trips to China, propaganda material, and invitations to the Embassy. With the Sino-Soviet Split, China encouraged the creation of pro-Chinese

\footnotetext{
${ }^{59}$ Swiss Embassy in Brussels, to EPD, 20 February 1963, SFA E2001E\#1976/17\#2071*; La Libre Belgique 25 December 1962; Couenoud, 'Restaurants chinois en Belgique,' 31 January 1963, SFA E2001E\#1976/17\#2071*; Bühlmann, 'Notiz,' 10 April 1961, SFA E4320C\#1994/78\#766*.

${ }^{60}$ Bühlmann, 'Notiz,' 22 March 1960, SFA E4320C\#1994/78\#605*.

${ }^{61}$ Bühlmann, 'Notiz,' 22 March 1960, SFA E4320C\#1994/78\#605*.

${ }^{62}$ Stahel, 'Verbindungen zur Botschaft der VR-China, Bern,' 11 November 1968, SFA E4320C\#1994/78\#695*.
} 
communist parties in Europe, and by late 1966, about 50 pro-Chinese organizations were thought to exist in Western Europe. The Embassy in Bern seems to have been the hub for contact with these organizations, and the Swiss government suspected that the Embassy assisted these groups financially. ${ }^{63}$ Chinese officials also collected information about leftwing organizations and their publications. ${ }^{64}$

Already in the 1950s, Bern had become a hub for China's network of communist contacts, which included members of various European communist parties as well as communist sympathisers. They travelled from all over Europe (particularly France, Italy, Belgium, and Western Germany) to Bern or Geneva to discuss Mao's writings, Chinese policies, and politics in their countries. In return, they received get directives, propaganda material, and in some cases also financial assistance. ${ }^{65}$ Interestingly, once China opened an embassy in Rome, the Swiss Marxist-Leninist Party (KPS/ML) suspected that the Chinese missions in Switzerland were under surveillance and usually travelled to Rome instead of Bern or Geneva whenever they wanted to meet Chinese diplomats. ${ }^{66}$

However, Bern seems to have been the main location for most European communists who wanted to get in touch with Chinese diplomats. Even French communists usually travelled to Bern instead of meeting officials in Geneva. In one case, three French communists from the Fédération des Cercles Marxistes-Leninistes de France travelled to the Embassy in Bern in 1955, where they spent eight hours discussing political issues, among other things, with the Chinese Cultural Attaché and received money. ${ }^{67}$ They were expelled for illegal political activity and received entry bans. In a conversation with the Chinese Ambassador Li Qingquan, the Political Department's head of Foreign Affairs, Hans Zimmermann, stated: 'we cannot tolerate such behaviour here'. However, Li replied: 'This embassy sees no reason to keep people away that want to uphold friendly relations with us', and he stated that the visits to the Embassy were 'voluntary'. ${ }^{68}$

\footnotetext{
${ }^{63}$ Kommissariat IV, 'Notiz. Monatsbericht Nr. 4/1969 der Verbindung IV,' 11 July 1969, SFA E4320C\#1994/78\#714*; Pahud to Politische Angelenheiten, 6 January 1964, SFA E2001E\#1978/84\#2315*; Blankart, 'Protokoll der Sitzumg vom 11. Sepbemter 1967 in Bern, Parlamentsgebäude Zimmer IV,' 27 September 1967, SFA BAR E2200.174\#1988/78\#53*. For the friendship associations see Cyril Cordoba, 'Audelà du Rideau de Bambou: amitiés culturelles et politiques avec la République populaire de Chine en Suisse (1949-1989)', forthcoming PhD, University of Fribourg, Switzerland.

${ }^{64}$ Hänzi, 'Aktennotiz,' 7 March 1951, SFA E4320B\#1981/141\#231*.

${ }^{65}$ See for example Babey, 'Intervention à l'encontre de 3 ressortissants français', 22 June 1965, SFA E2001E\#1978/84\#2315*.

${ }^{66}$ Personal correspondence with Willy Wottreng, a former leading member of the KPS/ML.

${ }^{67}$ Babey, 'Intervention à l'encontre de 3 ressortissants français', 22 June 1965, SFA E2001E\#1978/84\#2315*; Zimmermann to Swiss Embassy in Beijing, 30 June 1965, SFA E2200.174-02\#1981/200\#82*.

${ }^{68}$ Zimmermann, 'Besuchsnotiz,' 26 June 1965, SFA E2200.174-02\#1981/200\#82*.
} 
With the Sino-Soviet Split, China also became more active in Latin America, and from about 1960 visits by communists from Latin American countries to the Embassy in Bern increased. ${ }^{69}$ The case of Moema Vergara-Dutra from Brazil is interesting because it shows how the Embassy in Bern was part of an international network. Vergara-Dutra was questioned by the Police after she contacted the Chinese Cultural Attaché in Bern, Chang Yun, in February 1967. It turned out that she had been acting as a courier for the Brazilian Communist Party. Before she arrived in Bern she had met several contacts in Paris. After Bern, Vergara-Dutra was supposed to meet contacts in West and East Berlin, and Italy, passing on documents and instructions. ${ }^{70}$

The Embassy in Bern also organised trips by communists from all over the world to China, particularly in the 1960s. In most cases, the people flew to Switzerland, and spent a few days in Bern before they travelled onwards to China. ${ }^{71}$ It is likely that these days were used to pass on information or communications.

\section{Industrial Espionage and Intelligence}

According to Hannas, Mulvenon and Puglisi, the Chinese government relied both on open sources like foreign scientific literature and overseas scholars, as well as on espionage in its efforts to modernize China. ${ }^{72}$ China's industrial espionage in Cold War Europe can be put into two categories: firstly, technological information that could be used to copy Western production processes and products, and secondly, attempts to obtain embargo goods as well as scientific knowledge and know-how related to China's nuclear weapons program.

Until the late 1960s, Switzerland was China's window to Western markets, and the Chinese Trade Office in Muri (near Bern), which was established in 1954, was regarded as the most important one in Europe. ${ }^{73}$ Businessmen travelled from all over (Western) Europe to

\footnotetext{
${ }^{69}$ Bürgy, 'Zusammenfassender Bericht über die mit der chinesischen Botschaft in Verbindung stehenden Personen und Firmen,' 28 January 1964, SFA E4320C\#1994/78\#755*; Commisariat IV, 'Note,' 13 September 1966, SFA E4320C\#1994/78\#605*; Naville to Kohli, 22 March 1960, SFA E2300\#1000/716\#812*.

70 'Bericht der Bundespolizei betreffend ihre Feststellungen über die Tätigkeit der diplomatischen und konsularischen Vertretungen der Volksrepublik China in der Schweiz,' 1 September 1967, SFA E2001E\#1978/84\#2315*.

${ }^{71}$ See for example Spycher, 'Besucher aus Südamerika,' 2 February 1965, SFA E4320C\#1994/78\#766*.

${ }^{72}$ Hannas, Mulvenon and Puglisi, Chinese Industrial Espionage.

${ }^{73}$ Gygax to EPD Politische Angelegenheiten, 29 October 1957, SFA E2001E\#1976/17\#2085*; Armory, 'EXCON: Semi-Annual Appraisal of Significant Developments in Swiss Politico-Economic Relations with the Sino-soviet Bloc, January 1- June 20, 1962', National Archives (USNA), 1960-1963 CDF, RG 59, Box 1350,
} 
Muri to present their products and discuss potential imports and exports. Chinese delegations visiting European companies and factories to inspect goods and discuss potential deals also usually began their trips to Europe with a stay in Bern. ${ }^{74}$

Switzerland was a unique trading partner for China in Europe because after the Consultative Group's China Committee (CHINCOM) agreed on embargo lists for China in 1952, Switzerland refused to adhere to them, instead following the gentlemen's agreement with the USA in 1951 (the so-called Hotz-Linder Agreement), which included quotas of embargo goods. ${ }^{75}$ Although many Swiss companies limited their exports to China in order to avoid provoking any retaliatory measures by the USA, Swiss companies exported goods to China that other countries would not. Switzerland also had a booming arms industry and exported war materials to NATO countries. However, since these weapons were on the embargo list, they could not be exported to China, and information about their production process was not supposed to be shared with China. ${ }^{76}$ Nevertheless, as early as 1958 the Federal Police admitted that Swiss companies specializing in weapons production were targeted by Eastern bloc countries and that intelligence on the development of various weapons had been successfully obtained. ${ }^{77}$

Eftimiades has claimed that trade delegations have traditionally been used in espionage to obtain intelligence, ${ }^{78}$ and trade delegations and factory visits were also part of China's intelligence activities in Switzerland. The staff of the Chinese Trade Office in Muri visited Swiss companies and factories on an almost weekly basis. Very few companies refused to let the Chinese visit their production sites. In 1956, a Federal Police detective noted that the Chinese Military Attaché was often part of these delegations. ${ }^{79}$ Although it was suspected that he was interested in embargo products, it was only in 1959 that the Federal Police had gathered such evidence. During a visit to a company in Geneva that produced weapons for NATO countries, the Military Attaché insisted on being shown how some of the

654.60/12-1862; Naville to EPD Politische Angelegenheiten, 5 January 1961, SFA E2001E\#1976/17\#2085*; Handelsabteilung to EPD, 1 January 1961, SFA E2001E\#1976/17\#2085*.

${ }^{74}$ Rüfenacht, 'Handelsabteilung der Chinesischen Botschaft in Bern,' 23 April1958, SFA

E4320B\#1981/141\#232*; Caviezel, 'Tätigkeit der Chinesischen Botschaft in Bern,' 22 January 1957, ESFA 4320B\#1981/141\#231*.

75 'West-Ost Handel,' 28 July 1951, SFA E2200.174-02\#1968/2\#94*; Troendle to Swiss Embassy in Beijing, 19 November 1953, SFA E2200.174-02\#1968/2\#94*.

${ }^{76}$ Handelsabteilung to Rezzonico, 10 December 1951, SFA E2200.174-02\#1968/2\#94*; 'Aktennotiz,' 4 October 1957, SFA E2001E\#1976/17\#2118*; Steutz to Direction de l'Administration militaire fédérale, 29 March 1956, SFA E2001E\#1976/17\#2118*; Handelsabteilung to EPD Politische Angelegenheiten, 12 May 1955, SFA E2001E\#1976/17\#2118*; Handelsabteilung to EPD Politische Angelegenheiten, 12 July 1957 SFA E2001E\#1976/17\#2118*.

77 'Bericht der Bundespolizei,' 4 June1958, SFA E2001E\#1976/17\#2071*.

78 Eftimiades, Chinese Intelligence Operations, 42.

${ }^{79}$ Caviezel, 'Tätigkeit der Chinesischen Botschaft in Bern,' 20 November 1956, SFA E4320B\#1981/141\#231*. 
weapons were produced. However, the company refused to do so and scheduled a later visit on a Saturday because there would have been no workers present. ${ }^{80}$ A report from 1959 stated with regards to the frequent visits by the Chinese staff to Swiss companies: 'The danger that economic espionage is undertaken during such company visits is there, but it can be limited to a minimum by correct behaviour of the Swiss export businesses. ${ }^{\text {}}{ }^{81}$ As has been shown, this certainly was true in some cases but by no means all.

Throughout the 1950s and 1960s, commercial and scientific delegations from China flew to Switzerland to begin their travels through Europe. Usually, they spent a few weeks in Switzerland visiting factories and companies before travelling abroad. Many of these visits were arranged on short notice, which made it harder for the Federal Police and the Immigration Office to vet the members of the delegations and control their movements in Switzerland. Swiss companies also complained that the Chinese tried to visit parts of the factories that had nothing to do with the products they claimed to be interested in. ${ }^{82} \mathrm{~A}$ Federal Police report from 1962 dealt with the efforts of Chinese diplomats to gain access to technical and economic information and noted: 'The Swiss factory owners and businessmen who travel to China are not only surprised but shocked to see how well informed the Chinese are, even in the smallest details, about their companies. ${ }^{93}$

Even if companies managed to hide their production processes from Chinese prying eyes, the Chinese had other ways of legally obtaining this information. In 1957, the Swiss Ambassador in Beijing, Fernand Bernoulli, wrote that the Chinese had bought machines in Switzerland and Sweden which they then tried to copy even though they were under copyright. ${ }^{84}$ Such behaviour was typical. In a report from 1958, Bernoulli claimed that the Chinese copied any kind of Western product with utter disregard for copyrights. He also prophesied that the Chinese would match the quality of Swiss watch brand Tissot in 5 years, and Omega and Longines in 10 years. ${ }^{85}$ However, Western companies were aware of the risk

\footnotetext{
${ }^{80}$ Ritschard, 'Visite des usines Hispano-Suiza à Genève par une délégation chinoise,' 4 March 1945, SFA E4320B\#1981/141\#232*.

${ }^{81}$ Petitpierre to Wahlen, 23 February 1959, SFA E2001E\#1976/17\#2078*.

82 'Betr. Einreise einer chinesischen Wirtschafts- und technischen Delegation,' 7 February 1958, SFA E4320B\#1981/141\#232*; Bundespolizei to Sikripo Bern, 29 July 1957, SFA E4320B\#1981/141\#231*.

${ }^{83}$ Bundespolizei, 'Les Services de renseignements et de securité de la Republique Populaire de Chine,' September 1962, SFA E4320C\#1994/78\#750*.

${ }^{84}$ Bernoulli to Homberger, 3 April 1957, Vorort Archiv, Archiv für Zeitgeschichte (AfZ) 380.1.1.

${ }^{85}$ Bernoulli, 'Le conflit Est-Ouest vu de Pékin, 7 May 1958.
} 
of China copying their products because copyright issues with China had existed since the early $20^{\text {th }}$ century. ${ }^{86}$

Hannas, Mulvenon and Puglisi have shown that since the 1950s, China has systematically used open sources to access Western science and technology intelligence. This process, in Chinese called qingbaoxue (情报学), included the mining of scientific periodicals, government publications, conference proceedings and other publications, as well as scientific lectures and presentations. ${ }^{87}$ The collection of open source intelligence seems to have been a crucial part of the Chinese diplomatic staff's activities in Switzerland. In 1958, Bernoulli wrote from Beijing: 'Tons of foreign scientific publications of all kinds (Swiss, German, French, American etc.) are imported and immediately translated into Chinese. ${ }^{88}$ Indeed, Chinese diplomatic staff in Switzerland were often observed buying or ordering scientific journals and books. ${ }^{89}$ Moreover, the Military Attaché and his assistants not only tried to access technological information about the Swiss military but they also tried to buy publications on military topics from the USA, Britain, Canada, and other countries in Switzerland. ${ }^{90}$

Europeans also delivered scientific knowledge to China. For example, foreign trade exhibitions in China allowed the Chinese to gain insight into the European production processes and state of research. Furthermore, company representatives and scientists travelling to China were asked to give presentations about their products or technology. Hoping that this would increase their chances of a business deal, they were usually willing to do so. ${ }^{91}$

Chinese attempts to access Western scientific knowledge and obtain embargo goods became more urgent in the early 1960s with the Sino-Soviet Split because China lost access to Soviet knowledge and advisers as well as the chance for Chinese students to study in Russian universities. This led to an increase in interest in discussions with foreign scientists in China. In July 1964, the Swiss Ambassador in Beijing, Hans Keller, wrote: 'The Chinese use foreign exhibitions and trade shows systematically to obtain so urgently needed specialist

\footnotetext{
${ }^{86}$ Ariane Knüsel, 'A Tricky Business: Swiss Perceptions of Informal Imperialism in China in the 1920s,' Journal of Modern Chinese History 2 (2014): 210-229.

87 Hannas, Mulvenon and Puglisi, Chinese Industrial Espionage, 18-47.

${ }^{88}$ Bernoulli to Bühler, 8 September 1958, dodis.ch/15257.

${ }^{89}$ Bernoulli to Homberger, 3 April 1957, Vorort Archiv, Archiv für Zeitgeschichte (AfZ) 380.1.1.

${ }^{90}$ Bundespolizei, 'Les Services de renseignements et de securité de la Republique Populaire de Chine,' September 1962, SFA E4320C\#1994/78\#750*.

${ }^{91}$ Keller to Informationsdienst, 28 January 1965, SFA E2001E\#1978/84\#2384*; Bernoulli to Bühler, 8 September 1958, dodis.ch/15257.
} 
knowledge.' He stated that some of the discussions and presentations during foreign exhibitions and trade shows had become 'virtual interrogations'. ${ }^{92}$

Of course, there were also illegal ways that China attempted to obtain embargo goods or information about them. Unfortunately, there exists very little literature on such measures in the 1950s and 1960s. Among the few known examples is Liang Sili's mission in 1957 to buy theodolites, missiles and other equipment in Switzerland as part of a commercial delegation. ${ }^{93}$ Instead, publications tend to focus on China's industrial espionage in the 1990s and later, when China's economy had changed considerably due to the reforms introduced under Deng Xiaoping. As a result, most industrial espionage measures described by Mattis, Eftimiades, and Hannas, Mulvenon and Puglisi would not have been possible in the 1950s and 1960s. ${ }^{94}$ Instead, the people involved in illegal deals with the Chinese Embassy in Bern were part of an intricate international business network with members in European countries, Hong Kong, and even the USA that dealt with obtaining and relaying sensitive information on banned goods (usually war material), processing financial transactions, and even buying certain products under false premises and then handing them over to contacts, who in turn passed them on until they arrived in China. Contrary to other intelligence networks operated by the Chinese, the business network almost solely consisted of non-Chinese Westerners. ${ }^{95}$

Based on the sheer volume and content of the Federal Police's files, Chinese commercial espionage seems to have outweighed other Chinese intelligence activity in Switzerland. Yet, the Swiss authorities were usually quite lenient about it. This was also the case with the German Democratic Republic as Ricardo Tarli and Andreas Förster have shown. ${ }^{96}$ One explanation for this is that, to the Federal Police, communist subversion and intelligence activity was regarded as clear a threat to Swiss security while most business deals were not, even if they involved embargo goods. For example, a German businessman was known to have obtained embargo goods and information about embargo goods for the Chinese, and even admitted to having done so. However, for the Federal Police it was much

\footnotetext{
${ }^{92}$ Keller, 'Politischer Bericht No. 15,' 18 July 1964, SFA E2300\#1000/716\#815* (quote); Keller, 'Politischer Bericht No. 6,' 9 June 1964, SFA E2300\#1000/716\#815*. For the Sino-Soviet split's effects on China's nuclear program see Zhihua Shen and Yafeng Xia, Mao and the Sino-Soviet Partnership, 1945-1959 (Lanham: Lexington Books, 2015), 205-240 and Lüthi, Sino-Soviet Split.

${ }_{93}$ Zuoyue Wang, 'The Cold War and the Reshaping of Transnational Science in China,' in Science and Technology in the Global Cold War, ed. Naomi Oreskes and John Krige (eds), (Cambridge: MIT Press, 2014), 357.

${ }^{94}$ Hannas, Mulvenon and Puglisi, Chinese Industrial Espionage; Eftimiades, Chinese Intelligence Operations; Mattis, 'Chinese Intelligence'.

${ }^{95}$ Ariane Knüsel, 'Swiss Counterintelligence.'

${ }^{96}$ Riccardo Tarli, Operationsgebiet Schweiz: Die dunklen Geschäfte der Stasi (Zürich: Orell Füssli Verlag, 2015); Andreas Förster, Eidgenossen contra Genossen: Wie der Schweizer Nachrichtendienst DDR-Händler und Stasi-Agenten überwachte (Berlin: C.H. Links Verlag, 2016).
} 
more important to determine whether or not he had been complicit in intelligence activity for the Chinese. ${ }^{97}$

\section{Conclusion}

This article set out to provide an overview of the intelligence networks run by Chinese diplomatic staff in Switzerland in the 1950s and 1960s. It has been shown that Switzerland was ideally located as an intelligence hub for the Chinese because it was the site of China's first diplomatic mission in central Western Europe, which made it very accessible for most Europeans, while the large number of diplomats present due to Switzerland's neutrality and the UN headquarters in Geneva meant that Chinese officials could not only establish intelligence networks with Taiwanese diplomats in Europe and UN officials from New York, but also with diplomats from all over the world. China's operation of intelligence networks in Switzerland was also facilitated by the Swiss government's insistence that the Federal Police only investigate threats to Swiss security, and the government's reluctance to use measures to stop Chinese intelligence operations that could have threatened Swiss diplomats and Swiss companies in China as well as Switzerland's reputation as a neutral mediating power between the Cold War blocs. As a result, Chinese officials established and successfully ran a variety of European and even global intelligence networks out of Switzerland, whose members included diplomats; Chinese, Taiwanese, and Chinese Indonesian scientists and students; owners and staff of Chinese restaurants; Communists and communist sympathisers; and businessmen.

This article's findings support the view that Chinese intelligence did not rely purely on ethnic Chinese. Evidence from the Swiss Federal Archives strongly suggests that while certain intelligence networks operated from Bern and Geneva were predominantly, if not entirely, ethnic Chinese (for example student contacts or diplomats), there were other networks with members who were mainly Europeans without Chinese roots (for example businessmen involved in industrial espionage or embargo deals or communist subversion networks). There were even a few non-Chinese UN diplomats and scientists who were thought to have been acting as intelligence agents. It is, of course, possible that there were many more, and that either the police did not identify them, or their archival records are still classified. In any case, however, ethnic recruitment was not only typical for Chinese

\footnotetext{
97 ‘Abhörungsprotokoll,’ 21 June 1961, SFA E4320C\#1994/78\#677*.
} 
intelligence. According Wettering, for example, ethnic recruiting is still typical for foreign secret services in the USA. ${ }^{98}$

The question remains why so many ethnic Chinese were recruited. Mattis argues that the selection of ethnic Chinese agents by Chinese intelligence was 'more likely the result of their access or opportunities. ${ }^{99}$ Swiss evidence seems to indicate that the selection of ethnic Chinese was based on particular access or skills that the Chinese were interested in or that the reimbursement offered by China appealed particularly to ethnic Chinese. In the 1950s and 1960s, one of China's main interests was gaining information on Taiwan, the UN, and on science and technology. As a result, China recruited the most suitable spies and informants for this, which happened to be Taiwanese, Chinese, and Chinese Indonesians. They were also most likely to be swayed to eventually return to China or collaborate with China in order to enable their parents to move to China or improve their lives there. It could also be argued that Chinese officials in Switzerland had easiest access to Taiwanese, Chinese, and Chinese Indonesians because of Embassy matters like passport or visa requests.

Eftimiades also discusses the importance of third-country control operations for Chinese intelligence. ${ }^{100}$ As has been shown in this article, Switzerland was popular among members of China's intelligence networks for passing on classified information such as UN documents from New York and receiving instructions. Although the main culprits seem to have been UN officials and Taiwanese diplomats from Europe, it is possible that double agents from the USA or the UK also used conferences and meetings in Switzerland to pass on intelligence but I have not encountered such files.

There are also some aspects of Chinese intelligence in Cold War Europe that differ considerably from the accounts of Eftimiades, Mattis, and Hannas, Mulvenon and Puglisi, such as Chinese industrial espionage. However, since their studies mainly concern the period after Deng Xiaoping's economic reforms, it should hardly be surprising that some of the methods they describe (like the purchasing of American companies) did not occur in Europe during the 1950s and 1960s, when the Chinese government controlled foreign and domestic trade. Thus, China's industrial espionage changed considerably after China's opening in the late 1970s.

\footnotetext{
${ }^{98}$ Wettering, 'Counterintelligence,'275.

${ }^{99}$ Mattis, 'Chinese Intelligence,' 682.

${ }^{100}$ Eftimiades, Chinese Intelligence Operations, 51-52.
} 
Another difference is the issue of Chinese moles in foreign governments, such as Jin Wudai. ${ }^{101}$ I have not found any evidence of Chinese double agents in the Swiss government. Contrary to the UK or the USA, China probably had neither interest nor opportunity in placing moles in the Swiss government. After all, Switzerland was not a global player or of particular geopolitical interest to China.

It remains to be seen how exactly China's intelligence networks run from Bern differed from those in other European countries, but as long as other archives keep the relevant records classified, this will be difficult to determine unless more eyewitnesses come forward. After all, newspaper articles on Chinese intelligence were notoriously sensational and should not be taken at face value. It would also be interesting to find out just how large the intelligence networks were. The current estimates depend on the discoveries of the Swiss authorities but it is, of course, possible that there were more intelligence agents among Chinese officials in Switzerland and that the officials had contact with far more agents and informants than the Swiss government realised. In any case, since the Chinese officials in Bern and Geneva had contact with informants and spies from all over the world and particularly from Europe, it seems very likely that Switzerland was indeed the main hub for China's intelligence networks in Europe in the 1950s and 1960s.

${ }^{101}$ Eftimiades, Chinese Intelligence Operations, 46-51. 